\title{
Tracking the virus-like particles of Macrobrachium rosenbergii nodavirus in insect cells
}

\author{
Ummi Fairuz Hanapi ${ }^{1}$, Chean Yeah Yong ${ }^{1}$, Zee Hong Goh ${ }^{1}$, Noorjahan Banu Mohammed Alitheen ${ }^{2,3}$, Swee \\ Keong Yeap ${ }^{4}$, Wen Siang Tan Corresp. 1,3 \\ ${ }^{1}$ Department of Microbiology, Faculty of Biotechnology and Biomolecular Sciences, Universiti Putra Malaysia, Serdang, Selangor, Malaysia \\ 2 Department of Cell and Molecular Biology, Faculty of Biotechnology and Biomolecular Sciences, Universiti Putra Malaysia, Serdang, Selangor, Malaysia \\ 3 Institute of Bioscience, Universiti Putra Malaysia, Serdang, Selangor, Malaysia \\ 4 Xiamen University Malaysia, Sepang, Selangor, Malaysia \\ Corresponding Author: Wen Siang Tan \\ Email address: wstan@upm.edu.my
}

Macrobrachium rosenbergii nodavirus ( $M r N v$ ) poses a major threat to the prawn industry. Currently, no effective vaccine and treatment are available to prevent the spread of MrNv. Its infection mechanism and localisation in a host cell are also not well characterised. The MrNv capsid protein (MrNvc) produced in Escherichia coli self-assembled into virus-like particles (VLPs) resembling the native virus. Thus, fluorescein labelled MrNvc VLPs were employed as a model to study the virus entry and localisation in Spodoptera frugiperda, Sf9 cells. Through fluorescence microscopy and sub-cellular fractionation, the MrNvc were shown to enter Sf9 cells, and eventually arrived at the nucleus. The presence of MrNvc within the cytoplasm and nucleus of Sf9 cells was further confirmed by the Z-stack imaging. The presence of ammonium chloride $\left(\mathrm{NH}_{4} \mathrm{Cl}\right)$, genistein, methyl- $\beta$-cyclodextrin or chlorpromazine (CPZ) inhibited the entry of MrNvc into Sf9 cells, but cytochalasin D did not inhibit this process. This suggests that the internalisation of MrNvc VLPs is facilitated by caveolae- and clathrin-mediated endocytosis. The whole internalisation process of MrNvc VLPs into a Sf9 cell was recorded with live cell imaging. We have also identified a potential nuclear localization signal (NLS) of MrNvc through deletion mutagenesis and verified by classical-NLS mapping. Overall, this study provides an insight into the journey of MrNvc VLPs in insect cells. 
1 Tracking the virus-like particles of Macrobrachium rosenbergii nodavirus in insect cells

2

3 Ummi Fairuz Hanapi ${ }^{1}$, Chean Yeah Yong ${ }^{1}$, Zee Hong Goh ${ }^{1}$, Noorjahan Banu Mohammed

4 Alitheen ${ }^{2,3}$, Swee Keong Yeap ${ }^{4}$, and Wen Siang Tan ${ }^{1,3, *}$

5

$6 \quad{ }^{1}$ Department of Microbiology, Faculty of Biotechnology and Biomolecular Sciences, Universiti

7 Putra Malaysia, 43400 Serdang, Selangor, Malaysia.

8 2Department of Cell and Molecular Biology, Faculty of Biotechnology and Biomolecular

9 Sciences, Universiti Putra Malaysia, 43400 Serdang, Selangor, Malaysia.

$10{ }^{3}$ Institute of Bioscience, Universiti Putra Malaysia, 43400 Serdang, Selangor, Malaysia.

$11{ }^{4}$ Xiamen University Malaysia, 43900 Sepang, Selangor, Malaysia.

$13 *$ Correspondence:

14 Wen Siang Tan

15 Department of Microbiology

16 Faculty of Biotechnology and Biomolecular Sciences

17 Universiti Putra Malaysia

1843400 Serdang, Selangor, Malaysia.

19 Tel: 603-89466715; Fax: 603-89430913

20 Email: wstan@upm.edu.my; wensiangtan@yahoo.com 


\section{ABSTRACT}

24

Macrobrachium rosenbergii nodavirus $(M r \mathrm{Nv})$ poses a major threat to the prawn industry.

Currently, no effective vaccine and treatment are available to prevent the spread of $\mathrm{Mr} \mathrm{Nv}$. Its infection mechanism and localisation in a host cell are also not well characterised. The $\mathrm{MrNv}$ capsid protein $(\mathrm{MrNvc})$ produced in Escherichia coli self-assembled into virus-like particles (VLPs) resembling the native virus. Thus, fluorescein labelled $M r N v c$ VLPs were employed as a model to study the virus entry and localisation in Spodoptera frugiperda, Sf9 cells. Through fluorescence microscopy and sub-cellular fractionation, the $\mathrm{MrNvc}$ were shown to enter Sf9 cells, and eventually arrived at the nucleus. The presence of $M r N v c$ within the cytoplasm and nucleus of Sf9 cells was further confirmed by the Z-stack imaging. The presence of ammonium chloride $\left(\mathrm{NH}_{4} \mathrm{Cl}\right)$, genistein, methyl- $\beta$-cyclodextrin or chlorpromazine $(\mathrm{CPZ})$ inhibited the entry of $\mathrm{MrNvc}$ into Sf9 cells, but cytochalasin D did not inhibit this process. This suggests that the internalisation of $M r \mathrm{Nvc}$ VLPs is facilitated by caveolae- and clathrin-mediated endocytosis. The whole internalisation process of $M r N v c$ VLPs into a Sf9 cell was recorded with live cell imaging. We have also identified a potential nuclear localization signal (NLS) of $M r N v c$ through deletion mutagenesis and verified by classical-NLS mapping. Overall, this study provides an insight into the journey of $M r \mathrm{Nvc}$ VLPs in insect cells. 
44

45

46

47

\section{INTRODUCTION}

Macrobrachium rosenbergii or commonly known as the giant freshwater prawn is commercially grown in Asia, Western Pacific Islands and South America (Pillai \& Bonami, 2012). However, the white tail disease (WTD) caused by Macrobrachium rosenbergii nodavirus (MrNv) is currently the biggest problem that devastates the giant freshwater prawn farming, which always results in 100\% mortality (Qian et al., 2003; Nair \& Salin, 2012). Post-larvae diagnosed with WTD have a whitish colouration on the abdominal and tail segments as well as muscle (Bonami \& Widada, 2011). Post-larvae of $M$. rosenbergii are more susceptible to $M r \mathrm{Nv}$ infection and adult prawns are believed to be the virus carriers (Hayakijkosol \& Owens, 2013).

$M r \mathrm{Nv}$ is classified in the family Nodaviridae. Being rather distinctive to other nodaviruses, $M r \mathrm{Nv}$ has been proposed to be placed into a new genus, Gammanodavirus (Naveenkumar et al., 2013). The virus particle has an icosahedral and non-enveloped capsid of about $27 \mathrm{~nm}$ in diameter (Qian et al., 2003), encapsidating bipartite single stranded RNAs: RNA1 of about $2.9 \mathrm{~kb}$ encoding the RNA-dependent RNA polymerase; RNA2 of approximately $1.26 \mathrm{~kb}$ encodes the capsid protein. The capsid gene has been cloned into a bacteria plasmid and the recombinant $M r \mathrm{Nv}$ capsid protein ( $M r \mathrm{Nvc})$ self-assembled into virus-like particles (VLPs), resembling the native $M r N v$ isolated from infected prawns (Goh et al., 2011). By studying these VLPs, the RNA binding domain of $M r \mathrm{Nv}$ was located at amino acids 20-29 of the capsid protein (Goh et al., 2014). Therefore, $M r N v c$ VLPs provide an alternative method to study the virus structure and its functions in host cells.

The entry, trafficking and localisation of nodaviruses in their host cells were obtained mainly through the study of Flock House virus (FHV), an Alphanodavirus. FHV enters Drosophila melanogaster cells through receptor-mediated endocytosis which requires an acidic 
68 condition. Pre-treatment of cells with $\mathrm{NH}_{4} \mathrm{Cl}$ and bafilomycin A1 prevented acidification of endosomes and inhibited FHV's infection (Odegard, Banerjee \& Johnson, 2010). Under normal condition, internalized FHV is enclosed in an acidic endosome. The acidic $\mathrm{pH}$ in the endosomal compartment triggers conformational changes of the viral capsid proteins which expose and release the proteolytically cleaved $4.4 \mathrm{kDa}$ gamma $(\gamma)$ peptides. The particle associated $\gamma$ peptides then disrupt the endosomal membrane to facilitate the release of viral RNAs and nucleocapsid into the cytoplasm (Odegard, Banerjee \& Johnson, 2010).

FHV does not translocate into nucleus. On the other hand, greasy grouper nervous necrosis virus (GGNNV), a Betanodavirus, was found not only in the cell cytoplasm, but also in the nucleolus (Guo, Dallmann \& Kwang, 2003). A 9-residue peptide $\left({ }^{23}\right.$ RRRANNRRR $\left.{ }^{31}\right)$ located at the N-terminal region of the viral capsid protein and highly rich in positively charged amino acids, was identified as a nucleolus targeting sequence of GGNNV. This 9-residue peptide shares some similarities with the RNA-binding region of $\mathrm{MrNvc}\left({ }^{20} \mathrm{KRRKRSRRNR}{ }^{29}\right)$ located at the Nterminal end of the viral capsid protein (Goh et al., 2014). This indicates that the RNA-binding region of $M r \mathrm{Nvc}$ could be the nucleolus targeting sequence.

Recently, Somrit et al. (2016) successfully infected Spodoptera frugiperda, Sf9 cells with $M r \mathrm{Nv}$. They revealed that the $M r \mathrm{Nv}$ infected Sf9 cells through a caveolae-mediated endocytosis pathway. The main aim of the current study was to trace the trafficking of $M r N v c$ VLPs in Sf9 cells and compare with that of the live virus. Thus, the MrNvc VLPs were labelled with NHSfluorescein and their movement from the cell surface to the nucleus was studied with fluorescence microscopy, live cell imaging system and sub-cellular fractionation. This is the first report on the trafficking of $M r \mathrm{Nvc}$ VLPs in Sf9 cells. 
91

92

93

94

95

96

97

\section{MATERIALS AND METHODS}

\section{Purification of $M r N v c$ VLPs}

Expression and purification of the $M r \mathrm{Nvc}$ and its N-terminal deletion mutants $(9 \Delta M r \mathrm{Nvc}$, $19 \Delta M r \mathrm{Nvc}, 29 \Delta M r \mathrm{Nvc}$ and $20-29 \Delta M r \mathrm{Nvc}$ ) were as described previously by Goh et al. (2011; 2014). Briefly, E. coli cells harbouring the recombinant plasmids were grown in Luria-Bertani broth $(500 \mathrm{ml})$ containing ampicillin $(50 \mathrm{mg} / \mathrm{ml})$ at $220 \mathrm{rpm}$ for overnight. E. coli cultures were induced for recombinant protein expression with IPTG $(1 \mathrm{mM})$ at $37^{\circ} \mathrm{C}$ for $5 \mathrm{~h}$. Cells were then pelleted and lysed in lysis buffer (25 mM HEPES, $500 \mathrm{mM} \mathrm{NaCl} ; \mathrm{pH}$ 7.4) by adding phenylmethylsulfonyl fluoride (PMSF, $2 \mathrm{mM}), \mathrm{MgCl}_{2}(4 \mathrm{mM})$, freshly prepared lysozyme $(0.2$ $\mathrm{mg} / \mathrm{ml})$ and DNase $1(0.02 \mathrm{mg} / \mathrm{ml})$. After $2 \mathrm{~h}$ of incubation at room temperature (RT), the cells were sonicated at $200 \mathrm{~Hz}, 15$ times with $15 \mathrm{~s}$ interval. The mixture was centrifuged at $10,000 \times \mathrm{g}$ and supernatant was loaded into HisTrap HP columns (1 ml; GE Healthcare, Buckinghamshire, United Kingdom). Washing buffer A (25 mM HEPES, $500 \mathrm{mM} \mathrm{NaCl}, 50 \mathrm{mM}$ imidazole; $\mathrm{pH}$ 7.4) and $\mathrm{B}(25 \mathrm{mM}$ HEPES, $500 \mathrm{mM} \mathrm{NaCl}, 200 \mathrm{mM}$ imidazole; $\mathrm{pH}$ 7.4) were used to wash the unbound proteins. Elution buffer (25 mM HEPES, $500 \mathrm{mM} \mathrm{NaCl,} 500 \mathrm{mM}$ imidazole; pH 7.4) was used to elute $M r \mathrm{Nv}$ recombinant proteins. Eluted capsid proteins were dialysed in HEPES buffer (25 mM HEPES, $150 \mathrm{mM} \mathrm{NaCl}$; pH 7.4) at $4^{\circ} \mathrm{C}$, overnight.

\section{Fluorescence microscopy}

NHS-fluorescein (1 mg; Thermo Scientific, Rockford, USA) was dissolved in DMSO (100 $\mu \mathrm{l})$. Dialysed $M r$ Nvc VLPs $(100 \mu \mathrm{g})$ were incubated with NHS-fluorescein solution $(0.01 \mathrm{mg} / \mathrm{ml})$ at 
$1144^{\circ} \mathrm{C}$ for $24 \mathrm{~h}$ and then dialysed in HEPES buffer for $24 \mathrm{~h}$. Sf9 cells (ATCC ${ }^{\circledR} \mathrm{CRL}-1711^{\mathrm{TM}} ; 8 \times 10^{5}$

115 cells) were seeded on glass coverslips in a 6-well culture plate with Sf900 II SFM medium (2 ml;

116 GIBCO, Grand Island, NY, USA) for $24 \mathrm{~h}$ and the medium in each well was changed with a

117 fresh medium. The fluorescein labelled VLPs (F-MrNvc VLPs) were filtered with a membrane

118 filter $(0.4 \mu \mathrm{m})$ and the filtered VLPs $(25 \mu \mathrm{g})$ were added into the culture plates in triplicates.

119 Non-labelled $M r N v c$ VLPs were used as negative controls. The cells were incubated for $16 \mathrm{~h}$ at 120 RT to allow maximum nuclear translocation of $M r N v c$. The cells in each well were then 121 incubated with the Cell Tracker ${ }^{\mathrm{TM}}$ Orange CMTMR Dye $(0.5 \mu \mathrm{M}$; Thermo Fisher Scientific, 122 Massachusetts, USA) in medium $(2 \mathrm{ml})$ for $30 \mathrm{~min}$ to stain the cell cytoplasm. The coverslips were then washed with PBS (137 mM NaCl, $2.7 \mathrm{mM} \mathrm{KCl,} 4.3 \mathrm{mM} \mathrm{Na}_{2} \mathrm{HPO}_{4}, 1.47 \mathrm{mM} \mathrm{KH}_{2} \mathrm{PO}_{4}$; $124 \mathrm{pH}$ 7.4) for six times and the cells were fixed with paraformaldehyde (3.7\% in PBS; $\mathrm{pH} 7.4)$ for $12510 \mathrm{~min}$ at RT. One drop of NucBlue Live Ready Probe Reagent (Life Technologies, Carlsbad, 126 CA) was added to the mounting medium [1 ml; 90\% glycerol, $20 \mathrm{mM}$ Tris- $\mathrm{HCl}(\mathrm{pH} 8.5)$ and 100 $127 \mathrm{mM}$ propyl gallate] to stain the cell nucleus. A drop of mounting medium was placed on a glass 128 slide and the coverslip was carefully put on top of it. The edge of the coverslip was sealed with a 129 nail polish and the slides were observed under a fluorescence microscope, LEICA DM2500 130 (Leica Camera, Solms, Germany) with green (excitation filter BP 515-560; emission filter LP 131 590), blue (excitation filter BP 450-490; emission filter LP 515) and red (excitation filter BP 132 590-650; emission filter BP 700/75) filters under 40x objective.

133 Z-stack images were captured through the use of a confocal fluorescence microscope, 134 Olympus IX81 (Olympus, Tokyo, Japan) equipped with Disk Scanning Unit (DSU) for spinning 135 disk confocal [pinhole diameter 50-300 $\mu \mathrm{m}(1 \mu \mathrm{m}$ step)] under 60x objective. 


\section{Sub-cellular fractionation}

138 Fractionation of Sf9 cells was done according to the method described by Guo, Dallmann \& 139 Kwang (2003) with slight modifications on the buffers used. Confluent Sf9 cells in flasks (75 $\left.140 \mathrm{~cm}^{2}\right)$ were added with medium $(10 \mathrm{ml})$ containing $M r N v c$ VLPs $(1 \mathrm{mg})$ and incubated for $16 \mathrm{~h}$.

141 The subsequent steps were done at $4^{\circ} \mathrm{C}$. Cells were washed with ice-cold PBS (pH 7.4) for three 142 times. PBS (3 ml; pH 7.4) containing the Protease Inhibitor Cocktail $(10 \mu 1$; SIGMA Chemical 143 Co., St. Louis, MO, USA) was added before dislodging the cells from the culture flasks with a 144 cell scraper. The cells were harvested by centrifugation at $260 \times \mathrm{g}$ for $5 \mathrm{~min}$. Hypotonic buffer [20 $145 \mathrm{mM}$ HEPES (pH 7.9), $10 \mathrm{mM} \mathrm{KCl}, 1 \mathrm{mM}$ EDTA, $0.1 \mathrm{mM} \mathrm{Na} \mathrm{HPO}_{4}, 20 \mathrm{mM} \mathrm{NaF}, 10 \%$ 146 glycerol, 0.1\% tween-20, $1 \mathrm{mM}$ DTT, $1 \mathrm{mM}$ PMSF and 1\% Protease Inhibitor Cocktail] was 147 used to resuspend the cell pellets. The suspension was incubated for $30 \mathrm{~min}$ on ice. The 148 suspension was vortexed for $1 \mathrm{~min}$ and incubated on ice for $1 \mathrm{~min}$, and this process was repeated 149 for five times. The cytoplasmic extract of Sf9 cells was retrieved by centrifugation at $11,330 \times \mathrm{g}$ 150 at $4^{\circ} \mathrm{C}$ for $10 \mathrm{~min}$. The remaining pellet was washed with hypotonic buffer and centrifuged with 151 the same condition. The nuclear pellet was resuspended in hypotonic buffer (without tween-20) 152 with the addition of $\mathrm{NaCl}(420 \mathrm{mM})$ and glycerol $(20 \%)$. The suspension was vortexed as above 153 for 5 times. Then, the nuclear lysate was centrifuged at $11,330 \times \mathrm{g}$ at $4^{\circ} \mathrm{C}$ for $10 \mathrm{~min}$. The 154 supernatant containing nuclear extract was collected for further analysis with SDS-PAGE and 155 Western blotting.

157 SDS-PAGE and Western blot analysis

158 Cytoplasmic and nuclear extracts of Sf9 cells incubated with VLPs were electrophoresed in 159 SDS-polyacrylamide (12\%) gels at $16 \mathrm{~mA}$. The gels were stained with the Coomassie Brilliant 
160 Blue (CBB) dye. For Western blotting, the proteins on the gels were transferred onto

161 nitrocellulose membranes and blocked with skimmed milk (10\%; Anlene, Auckland, New

162 Zealand) in TBS buffer [50 mM Tris-HCl (pH 7.4) and $150 \mathrm{mM} \mathrm{NaCl}]$ for $1 \mathrm{~h}$. The membranes

163 were washed three times with TBST [50 mM Tris- $\mathrm{HCl}(\mathrm{pH} 7.4), 150 \mathrm{mM} \mathrm{NaCl}$ and $0.1 \%$ (v/v)

164 Tween-20] for $5 \mathrm{~min}$ each, and then incubated with anti-His antibody (1:5000 dilution with TBS;

165 GE Healthcare, Buckinghamshire, United Kingdom) or rabbit anti- $\mathrm{MrNv}$ serum (1:1000 dilution)

166 at $4^{\circ} \mathrm{C}$. After an overnight incubation, the membrane was washed again with TBST for five

167 times, $5 \mathrm{~min}$ each and incubated with anti-mouse $\operatorname{IgG}$ antibody conjugated to alkaline 168 phosphatase (1:5000 dilutions in TBS; KPL Inc., Maryland, USA) or anti-rabbit IgG (1:5000

169 dilution with TBS; SIGMA Chemical Co., St. Louis, MO, USA) overnight at $4^{\circ} \mathrm{C}$. After washing

170 five times with TBST, the protein bands were developed by adding 5-bromochloroindolyl-

171 phosphate $(3.3 \mu \mathrm{l} / \mathrm{ml})$ and nitrobluetetrazolium $(6.6 \mu \mathrm{l} / \mathrm{ml})$ in alkaline phosphatase buffer [100

$172 \mathrm{mM}$ Tris- $\mathrm{HCl}(\mathrm{pH} 9.5), 100 \mathrm{mM} \mathrm{NaCl}$ and $\left.5 \mathrm{mM} \mathrm{MgCl}_{2}\right]$.

173

174 Live cell imaging

175 Sf9 cells $\left(8 \times 10^{5}\right.$ cells $)$ were seeded in 6-well culture plates at RT for overnight. Fresh Sf900 II 176 SFM medium (2 ml) containing F-MrNvc VLPs $(25 \mu \mathrm{g} / \mathrm{ml})$ were added into the cells and 177 incubated for $1 \mathrm{~h}$ at $4^{\circ} \mathrm{C}$, followed by $30 \mathrm{~min}$ incubation at $\mathrm{RT}$ to initiate internalisation of the $178 M r$ Nvc VLPs. NucBlue Live Ready Probe Reagent (1 drop) and 3 mM propyl gallate were added 179 to stain the nucleus prior to viewing the uptake of $M r N v c$ VLPs by Sf9 cells across the plasma 180 membrane in real-time with Olympus IX81-DSU equipped with a high-sensitivity cooled CCD 181 (charge-coupled device) camera with a built-in shutter, which allows single DSU image to be 182 obtained in 0.1-0.4s and avoid photobleaching when no image is acquired. Fluorescence images 
183 were visualized by exciting the fluorescence at $493 \mathrm{~nm}$ (green for VLPs) and $360 \mathrm{~nm}$ (blue for 184 cell nucleus). Static superimposed images were captured every $30 \mathrm{~s}$ for $1 \mathrm{~h}$ duration and 185 compiled into a video to observe the VLPs uptake by the cells.

\section{Endocytosis inhibition assay}

188 Five endocytosis inhibitors were used to study the uptake mechanism of MrNvc VLPs into Sf9 189 cells. The Sf9 cells $\left(8 \times 10^{5}\right.$ cells $)$ were seeded on glass slides in each well of 6 -well culture plates for overnight. The Sf900II SFM medium was removed and the cells were pre-incubated in $2 \mathrm{ml}$

191

medium for $1 \mathrm{~h}$ at RT with: cytochalasin D ( $2 \mu \mathrm{M}$; Calbiochem, CA, USA), $\mathrm{NH}_{4} \mathrm{Cl}$ (10 mM; Bio Basic Inc., NY, USA), chlorpromazine (CPZ: $50 \mu \mathrm{M}$; Santa Cruz Biotechnology, Texas, USA), methyl- $\beta$-cyclodextrin (2 mM; Sigma-Aldrich, MO, USA) and genistein (100 $\mu \mathrm{M}$; Calbiochem, CA, USA). The cells were then incubated for another $16 \mathrm{~h}$ at RT following the addition of F$M r \mathrm{Nvc}$ VLPs $(25 \mu \mathrm{g} / \mathrm{ml})$. The coverslips were washed with PBS (pH 7.4) for six times and the cells were fixed with paraformaldehyde (3.7\% in PBS; pH 7.4) for $10 \mathrm{~min}$ at RT. A drop of mounting medium was placed on a glass slide and the coverslip was gently placed on top of it. The edge of the coverslip was sealed with a nail polish and the slides were observed under the Zeiss LSM5 PASCAL laser scanning microscope (Carl Zeiss, Oberkochen, Germany) excited with $488 \mathrm{~nm}$ laser (pinhole diameter $160 \mu \mathrm{m}$ ) under 63x objective.

\section{Cell viability assay}

The viability of Sf9 cells incubated in different endosomal inhibitors were analysed with 3-(4, 5dimethylthiazol-2-yl)-2, 5-diphenyltetrazolium bromide (MTT) assay. Sf9 cells $\left(100 \mu 1 ; 2 \times 10^{5}\right.$ cells $/ \mathrm{ml}$ ) were seeded on 96-well culture plates and incubated for $16 \mathrm{~h}$ at $\mathrm{RT}$ in a medium (100 
$206 \mu \mathrm{l})$ containing cytochalasin $\mathrm{D}(2 \mu \mathrm{M}), \mathrm{NH}_{4} \mathrm{Cl}(10 \mathrm{mM})$, chlorpromazine $(50 \mu \mathrm{M})$, methyl- $\beta$ -

207 cyclodextrin $(2 \mathrm{mM})$ and genistein $(100 \mu \mathrm{M})$. Sf9 cells without the inhibitors served as controls.

208 The MTT reagent $[10 \mu 1 ; 5 \mathrm{mg} / \mathrm{ml}$ in PBS (pH 7.4)] was added in each well and incubated at RT.

209 After $2 \mathrm{~h}$, the medium was removed and MTT solubilisation solution $(100 \mu \mathrm{l} ; 1: 9$ part of $10 \%$

210 SDS:DMSO) was added. The plate was incubated for $15 \mathrm{~min}$ in dark and the absorbance at 570

$211 \mathrm{~nm}$ was measured with the $\mu$ Quant ${ }^{\mathrm{TM}}$ ELISA plate reader (Bio Tek Instruments, Winooski, 212 USA).

213 The percentage of viable Sf9 cells was measured as [100-((A-B)/A×100)], where A is the 214 absorbance of the control cells and B is the absorbance of treated cells.

\section{RESULTS}

\section{MrNve VLPs internalise Sf9 cells}

Fluorescence microscopy was used to examine the delivery and localisation of fluoresceinlabelled $M r$ Nvc VLPs (F-MrNvc VLPs) in Sf9 cells. The VLPs labelled with NHS-fluorescein at the lysine residues of $\mathrm{MrNvc}$ were added to $\mathrm{Sf9}$ cells and incubated at room temperature (Fig. 1). To observe the dispersion of F-MrNvc VLPs in the Sf9 cells, the NucBlue Live Ready Probe Reagent and Cell Tracker Orange were used to stain the nuclear and cytosolic boundaries, respectively. No intense green fluorescence was detected from the normal Sf9 cells (Fig. 1A) and in the Sf9 cells incubated with non-labelled $M r N v c$ VLPs (Fig. 1B). After $16 \mathrm{~h}$ of incubation with the F-MrNvc VLPs, green fluorescence accumulated within the Sf9 cells (Fig. 1C),

227 indicating the internalisation of VLPs into the cells. From the merged images, $M r N v c$ VLPs were

228 clearly located at the cytoplasm of Sf9 cells. A close-up examination on the cells showed intense 
229 fluorescence spots of small granular appearance localised throughout the cell cytoplasm (Fig.

230 1D). Interestingly, the fluorescence spots tended to cluster at one side of the cells resembling 231 cap-like structures, which have also been reported by Liu et al. (2005) when SSN-1 cells were 232 infected with dragon grouper nervous necrosis virus (DGNNV), but not the VLPs.

233

234 MrNve distributes in Sf9 cell cytoplasm and nucleus

235 Sub-cellular fractionation was performed to verify the presence of $M r \mathrm{Nvc}$ in Sf9 cells. The cells 236 were incubated with $M r N v c$ VLPs at $0,4,8,12$ and $16 \mathrm{~h}$. At each time point, the cells were 237 disrupted by hypotonic buffer (HB) to fractionate the nuclear and cytoplasmic components. $238 M r \mathrm{Nvc}$ was detected by the rabbit anti-MrNv serum [Fig. 2A(i)] and anti-His antibody [Fig. $2392 \mathrm{~A}(\mathrm{ii})]$. In the cytoplasmic and nuclear fractions of Sf9 cells incubated with $M r \mathrm{Nvc}$ VLPs, a 240 distinct band corresponding to the $M r \mathrm{Nvc}$ with a molecular mass $\sim 46 \mathrm{kDa}$ was detected after $4 \mathrm{~h}$ 241 post-incubation. After $8 \mathrm{~h}$ of incubation, the $M r \mathrm{Nvc}$ was detected in the cell nucleus. In addition, 242 a smaller protein band of $\sim 44 \mathrm{kDa}$ was detected by the serum and anti-His antibody indicating it 243 is an N-terminal degraded product of $M r N v c$. Goh et al. (2014) and Yong et al. (2015a) also 244 reported that the $M r N v c$ VLPs produced in E. coli contained the N-terminal degraded product. 245 The Sf9 cells incubated with $M r N v c$ VLPs for $16 \mathrm{~h}$ were viewed under a fluorescence 246 microscope and 20 Z-stack images were captured. The orthogonal view of the cells was obtained 247 by using the ImageJ software. From the view of XY, YZ and XZ axes, it was confirmed that the $248 M r \mathrm{Nvc}$ VLPs, as indicated by the yellow line interceptions, were localised in the cell nucleus 249 (Fig. 2B) and cytoplasm (Fig. 2C). 


\section{Effect of endosomal inhibitors on the entry of MrNve VLPs into Sf9 cells}

$252 \mathrm{NH}_{4} \mathrm{Cl}(10 \mathrm{mM})$, cytochalasin $\mathrm{D}(2 \mu \mathrm{M})$, methyl- $\beta$-cyclodextrin $(2 \mathrm{mM}), \mathrm{CPZ}(50 \mu \mathrm{M})$ and 253 genistein $(100 \mu \mathrm{M})$ were used to study the entry mechanism of MrNvc VLPs in Sf9 cells. Sf9 254 cells were pre-incubated with the inhibitors, followed by the addition of F-MrNvc VLPs. After

$25516 \mathrm{~h}$, the cells were observed under a fluorescence microscope. The amount of green granular 256 appearance in Sf9 cells decreased drastically in the presence of $\mathrm{NH}_{4} \mathrm{Cl}, \mathrm{CPZ}$, methyl- $\beta$ 257 cyclodextrin and genistein [Fig. 3A (iv, v, vi, vii)]. These results suggest that $\mathrm{NH}_{4} \mathrm{Cl}$, methyl- $\beta$ 258 cyclodextrin, $\mathrm{CPZ}$ and genistein inhibited $M r \mathrm{Nvc}$ VLPs entry at the early event of endosomal 259 pathway in Sf9 cells. On other hand, cytochalasin D did not inhibit the VLPs entry [Fig. 3A 260 (iii)].

261 MTT assay was performed to assess $\mathrm{Sf9}$ cell viability in the presence of $\mathrm{NH}_{4} \mathrm{Cl}$, 262 cytochalasin D, CPZ, methyl- $\beta$-cyclodextrin and genistein. All treated cells have viability 263 percentage over $80 \%$ (Fig. 3B), indicating the treatments were not toxic to the cells.

The trafficking mechanism of MrNvc VLPs into Sf9 cells examined with live cell imaging 266 system

The internalisation process of $M r \mathrm{Nvc}$ VLPs into Sf9 cells was examined using a live cell imaging system. After $1 \mathrm{~h}$ pre-incubation at $4^{\circ} \mathrm{C}$, the $\mathrm{Sf} 9$ cells were incubated at RT for $30 \mathrm{~min}$. Time lapse video was captured for $1 \mathrm{~h}$ in $30 \mathrm{~s}$ interval (Video S1). As demonstrated in Fig. 4(A), VLPs attached on the cell surface were brought near to a membrane pit, which then accumulated into the middle of the pit (Fig. 4B). The VLPs were enclosed in the endosomes which move

272 freely in the cytosol (Fig. 4C, ) until the shape became disproportionate (Fig. 4D). The endosome 273 disappeared completely after a few minutes (Fig. 4E as annotated by red arrow), in which the 
$274 M r \mathrm{Nvc}$ is believed to be released into the cytosol. Endosome formation and endosomal escape

275 are summarised in a schematic diagram (Fig. 4F).

276

277 Incubation of Sf9 cells with the N-terminal deletion mutants of $\mathrm{MrNvc}$

278 The N-terminal region of $M r \mathrm{Nvc}$ is highly rich in positively charged residues (Goh et al., 2014).

279 The roles of this region in cell entry and internalization into nucleus were studied by four N280 terminally deleted mutants (Fig. 5A); namely $9 \Delta M r \mathrm{Nvc}, 19 \Delta M r \mathrm{Nvc}, 29 \Delta M r \mathrm{Nvc}$ and 20$28129 \Delta M r N v c$. The Sf9 cells incubated with the four deletion mutants and the full length $M r N v c$ 282 were subjected to sub-cellular fractionation (Fig. 5B) and viewed under a fluorescence

283

284

285

286

287

288

289

290

291

292

293

294

295

296 microscope with two labelling signals (Fig. 5C). Figure 5(B) shows that the full length $\mathrm{MrNvc}$ and the four mutants were detected in the cell cytoplasm by Western blotting. The green signal observed under fluorescence microscopy revealed that the fluorescein-labelled VLPs of all mutants and the full length capsid protein appear as green granules in the cell cytoplasm. This study confirmed the Western blot results demonstrating that the N-terminal region of the $M r \mathrm{Nvc}$ does not play a role in the entry of VLPs into Sf9 cells, and that the receptor binding site is located somewhere after amino acid 29 of $M r N v c$. Deletion of amino acids 20-29 (20$29 \Delta M r \mathrm{Nvc}$ ) significantly decreased the internalisation of $M r \mathrm{Nvc}$ into nucleus (Fig. 5B), as no trace of $20-29 \Delta M r N v c$ can be detected in the nuclear extract (analysed with the Quantity One Software), demonstrating the importance of these positively charged residues in nuclear localisation.

\section{DISCUSSION}


$298 M r$ Nvc produced in $E$. coli self-assembles into VLPs resembling the native virus isolated from 299 infected prawns (Goh et al., 2011). These VLPs have been used in a wide variety of studies, 300 including a fundamental study which has led to the discovery of the RNA-binding region in $301 M r N v c$ (Goh et al., 2014), and their applications as nano-particles for the delivery of DNA into 302 insect cells (Jariyapong et al., 2014), as well as the display of foreign epitopes such as those of 303 hepatitis B (Yong et al., 2015a) and influenza A (Yong et al., 2015b) viruses. As such, learning 304 the $M r N v c$ VLPs' mode of entry into cells will surely benefits its potential applications, 305 escpecially as a gene or drug delivery vehicle. Due to the ease of production and manipulation, the $M r \mathrm{Nvc}$ VLPs serve as an excellent model to study the $M r \mathrm{Nv}$ trafficking within host cells. Most recently, $M r \mathrm{Nv}$ has been shown to infect $\mathrm{Sf9}$ cells (Somrit et al., 2016). Therefore, in this study, the $M r N v c$ VLPs produced in E. coli were labelled with fluorescein and their localisation in Sf9 cells was studied with fluorescence microscopy, sub-cellular fractionation and live cell imaging system.

$\mathrm{MrNv}$ was reported to infect Macrobrachium rosenbergii (Hameed \& Yoganandhan, 2004) and Penaeus vannamei (Tang et al., 2007). In this study, we have demonstrated the ability of $M r \mathrm{Nvc}$ VLPs to internalise Sf9 cells. This suggests that the Sf9 cells and prawn cells share similar receptor for the binding of $M r \mathrm{Nv}$. Upon entry of $M r \mathrm{Nvc}$ VLPs, granules emitting green fluorescence were observed in the cytoplasm of Sf9 cells under a fluorescence microscope. These green granules are believed to be clusters of VLPs entrapped in endosomes. disrupt the function of endosome and its role in $\mathrm{MrNvc}$ VLPs uptake. $\mathrm{NH}_{4} \mathrm{Cl}$ raises the endocytic 319 $\mathrm{pH}$ and inhibits endosomal acidification. The appearance of green fluorescence spots in Sf9 cells 
320 incubated with $\mathrm{MrNvc}$ VLPs reduced significantly in the presence of $\mathrm{NH}_{4} \mathrm{Cl}(10 \mathrm{mM})$. This 321 suggests that the $M r N v c$ VLPs entered host cell via acidic endocytic pathway involving the

322 formation of endosomes. Treatment of Sf9 cells with genistein, which inhibits caveolae-mediated

323 endocytosis by inhibiting several tyrosine kinase functions in cells (Iversen, Skotland \& Sandvig,

324 2011), has reduced the uptake of $M r$ Nvc VLPs by Sf9 cells dramatically. This corresponded well

325 with the results reported by Somrit et al. (2016), who demonstrated that in the presence of 326 genistein, $M r \mathrm{NV}$ infection in $\mathrm{Sf} 9$ cells was reduced significantly. In addition, we tested the effect

327 of methyl- $\beta$-cyclodextrin towards $M r N v c$ VLPs internalisation, which is known to inhibit

328 caveolae-mediated endocytosis through cholesterol depletion in cells (Kim et al., 2012).

329 Depletion of green granular appearance in the Sf9 cells further confirmed the importance of 330 caveolae-mediated endocytosis towards the internalisation of MrNvc VLPs. Methyl- $\beta$ 331 cyclodextrin has also been reported to inhibit clathrin-mediated endocytosis (Rodal et al., 1999).

332 To verify the involvement of clathrin-mediated endocytosis, we studied the effect of CPZ, a 333 clathrin-mediated endocytosis inhibitor which inhibits Rho GTPase (Hussain et al., 2011; Kim et 334 al., 2012). Interestingly, the presence of CPZ halted the $M r N v c$ VLPs internalisation into Sf9 335 cells, suggesting that clathrin-mediated endocytosis also plays a role in the VLPs entry into Sf9 336 cells. To assess the involvement of macropinocytosis, cytochalasin D which inhibits actin 337 polymerisation was used in this study (Gold et al., 2010; Iversen, Skotland \& Sandvig, 2011). 338 From the results, no noticeable inhibition of VLP entry was observed, suggesting that the entry 339 mechanism is macropinocytosis-independent.

340 Following the attachment of $M r N v c$ VLPs on the cell surface and the requirement of an 341 acidic environment in early VLP entry, the formation of endosomes and endosomal escape of 342 VLPs were observed via a real-time live cell imaging system (Video S1). The early step for 
343 endosome formation is triggered by the attachment of VLPs on Sf9 cell surface. VLPs were

344 brought closer surrounding a membrane pit. The VLPs were later accumulated into the centre of

345 the pit. After a while, the VLPs were observed moving around freely in the cytoplasm in a 346 circular vesicle, which is believed to be an endosome. A disproportionate size and shape of the 347 endosome was observed, followed by fading and disappearance of the fluorescence signal, which 348 could indicate endosomal escape of the $M r N v c$ (Ohtsuki et al., 2015). During endosomal escape, $349 M r \mathrm{Nvc}$ was released into the cytosol. Kalia \& Jameel (2011) reported that virus particles stay in 350 an endocytic organelle until the conditions permit them to be released or when an endosome is 351 close to the nuclear pore for translocation into a nucleus. Since nodavirus is a non-envelope 352 virus, membrane fusion is unlikely to be involved in the endosomal escape.

353 Odegard et al. (2009) and Odegard, Banerjee \& Johnson (2010) proposed that the capsid 354 protein of FHV undergoes a conformational change in the acidic environment of endosome and 355 exposes the $\gamma$ peptide (44 residues) at its C-terminal end. This short peptide binds to the 356 endosomal membrane and disrupts the membrane to facilitate translocation of nucleocapsid into 357 the cytoplasm. However in the present study, the $\gamma$ peptide and its cleavage site [for FHV $358\left(\mathrm{Asn}^{363}-\mathrm{Ala}^{364}\right.$; Odegard, Banerjee \& Johnson, 2010) and Pariacoto virus (Asn ${ }^{361}-\mathrm{Ser}^{362}$; 359 Johnson, Zeddam \& Ball, 2000)] are not present at the C-terminal end of $M r N v c$ based on amino 360 acid sequence analysis. The C-terminal region of $M r N v c$ localised within the cell nucleus 361 remained intact, as the His-tag at the C-terminal end of the protein was detected by anti-His 362 antibody in Western blotting, suggesting that the $M r \mathrm{Nv}$ might use a different endosomal escape 363 mechanism compared to that of FHV. Many viruses contain a nuclear localisation signal (NLS) comprising basic amino acids 365 which allow them to enter the hosts' nuclei. These viruses include SV40 (Kalderon et al., 1984), 
366 hepatitis B virus (Li et al., 2010), BK polyomavirus (Bennett et al., 2015) and dengue virus

367 (Netsawang et al., 2010). Since FHV does not enter the host nucleus, GGNNV (a betanodavirus)

368 was used instead to illustrate the possible mechanism employed by $M r \mathrm{NV}$ in the nucleus

369 translocation. A highly basic 9-residue peptide $\left({ }^{23}\right.$ RRRANNRRR $\left.{ }^{31}\right)$ was identified in GGNNV as

370 a nucleus targeting sequence in fish and mammalian cells (Guo, Dallmann \& Kwang, 2003). The

371 N-terminal region of $M r \mathrm{Nvc}$ is also highly rich in positively-charged residues. A 10-residue

372 peptide, ${ }^{20} \mathrm{KRRKRSRRNR}^{29}$, was identified as the RNA-binding region (Goh et al., 2014). This

373 peptide shares some similarities with the NLS of GGNNV. Therefore, the N-terminal deletion

374 mutants of $M r \mathrm{Nvc}$ (Goh et al, 2014), namely $9 \Delta M r \mathrm{Nvc}, 19 \Delta M r \mathrm{Nvc}, 29 \Delta M r \mathrm{Nvc}$ and 20-

$37529 \Delta M r N v c$ were used to study their internalisation into Sf9 cells. The nuclear localisation ability

376 of the VLPs reduced dramatically for $20-29 \Delta M r N v c$ mutant. This suggests that the highly basic

377 residues located at residues 20-29 of $M r \mathrm{Nvc}$ are part of the nuclear targeting sequence. Amino

378 acid sequence analysis of $M r N v c$ with the cNLS mapper (Kosugi et al., 2009) revealed that the

$379{ }^{20} \mathrm{KRRKRSRRNR}^{29}$ of $M r \mathrm{Nvc}$ is a monopartite NLS with a score of 7.5 (max score of 10;

380 reflects the strength of NLS activities), indicating partial localisation to the nucleus based on an

381 importin- $\alpha$ dependent pathway. These findings suggest that the RNA binding domain of $M r \mathrm{Nvc}$

382 plays a vital role in the nuclear translocation of $M r \mathrm{NV}$. The dual function of RNA binding and

383 nucleus translocation of a highly basic peptide motif has also been reported in other viruses and 384 proteins, such as the Alfafa mosaic virus (Herranz, Pallas \& Aparicio, 2012) and human dicer 385 (Doyle et al., 2013). 
390 As a summary, fluorescence microscopy, sub-cellular fractionation and live cell imaging 391 revealed that $M r$ Nvc VLPs were localized in the cytoplasm and nucleus of the Sf9 cells. Upon 392 entry through the clathrin- and caveolae-mediated endocytosis, the $M r \mathrm{Nvc}$ was enclosed in 393 endosomes and escaped from this compartment with a mechanism different from FHV. The 394 highly basic RNA-binding domain located at positions 20-29 of the $\mathrm{MrNvc}$ does not play a role 395 in the VLP entry into the cytoplasm, however its function in nuclear translocation was 396 demonstrated. Overall, this study has shed some light on the journey of $M r \mathrm{Nvc}$ VLPs in an insect 397 cell, mimicking the native $M r \mathrm{Nv}$.

400

401

\section{ACKNOWLEDGEMENTS}

402

403 We thank Dr. Ho Kok Lian for his technical advices.

404

405

406

407

408

409

410

\section{REFERENCES}

411 
412 Adachi K, Ichinose T, Takizawa N, Watanabe K, Kitazato K, Kobayashi N. 2007. Inhibition of

413

414

415

416

417

418

419

420

421

422

423

424

425

426

427

428

429

430

431

432 betanodavirus infection by inhibitors of endosomal acidification. Archives of Virology 152: 2217-2224. doi: 10.1007/s00705-007-1061-7.

Bennett SM, Zhao L, Bosard C, Imperiale MJ. 2015. Role of a nuclear localization signal on the minor capsid proteins VP2 and VP3 in BKPyV nuclear entry. Virology 474: 110-116. doi: 10.1016/j.virol.2014.10.013.

Bonami J-R, Widada JS. 2011. Viral diseases of the giant fresh water prawn Macrobrachium rosenbergii: a review. Journal of Invertebrate Pathology 106: 131-142. doi: 10.1016/j.jip.2010.09.007.

Doyle M, Badertscher L, Jaskiewicz L, Guttinger S, Jurado S, Hugenschmidt T, Kutay U, Filipowicz W. 2013. The double-stranded RNA-binding domain of human Dicer functions as a nuclear localization signal. RNA 19: 1238-1252. doi: 10.1261/rna.039255.113.

Goh ZH, Tan SG, Bhassu S, Tan WS. 2011. Virus-like particles of Macrobrachium rosenbergii nodavirus produced in bacteria. Journal of Virological Methods 175: 74-79. doi: 10.1016/j.jviromet.2011.04.021.

Goh ZH, Mohd NAS, Tan SG, Bhassu S, Tan WS. 2014. RNA-binding region of Macrobrachium rosenbergii nodavirus capsid protein. Journal of General Virology 95: 1919-1928. doi: 10.1099/vir.0.064014-0.

Gold S, Monaghan P, Mertens P, Jackson T. 2010. A clathrin independent macropinocytosis-like entry mechanism used by bluetongue virus-1 during infection of BHK cells. PLoS One 5: e11360. doi: 10.1371/journal.pone.0011360. 
433 Guo YX, Dallmann K, Kwang J. 2003. Identification of nucleolus localization signal of 434 betanodavirus GGNNV protein $\alpha$. Virology 306: 225-235. doi: 10.1016/S0042-

435

436

437

438

439

440

441

442

443

444

445

446

447

448

449

450

451

452

453

454 6822(02)00081-8.

Hameed ASS, Yoganandhan K. 2004. Studies on the occurrence of Macrobrachium rosenbergii nodavirus and extra small virus-like particles associated with white tail disease of $M$. rosenbergii in India by RT-PCR detection. Diseases of Aquatic Organisms 238: 127-133. doi: 10.1016/j.aquaculture.2004.06.009.

Hayakijkosol O, Owens L. 2013. Non-permissive C6/36 cell culture for the Australian isolate of Macrobrachium rosenbergii nodavirus. Journal of Fish Diseases 36: 401-409. doi: 10.1111/j.1365-2761.2012.01414.x.

Herranz MC, Pallas V, Aparicio F. 2012. Multifunctional roles for the N-terminal basic motif of Alfafa mosaic virus coat protein: nucleolar/cytoplasmic shuttling, modulation of RNAbinding activity, and virion formation. Molecular Plant-Microbe Interactions 25: 1093-1103. doi: 10.1094/MPMI-04-12-0079-R.

Hussain KM, Leong KL, Ng MM, Chu JJ. 2011. The essential role of clathrin-mediated endocytosis in the infectious entry of human enterovirus 71. Journal of Biological Chemistry 286: 309-321. doi: 10.1074/jbc.M110.168468.

Iversen T-G, Skotland T, Sandvig K. 2011. Endocytosis and intracellular transport of nanoparticles: present knowledge and need for future studies Nano Today 6: 176-185. doi: 10.1016/j.nantod.2011.02.003.

Jariyapong P, Chotwiwatthanakund C, Somrita M, Jitrapakdeep S, Xinge L, Chenge HR, Weerachatyanukul W. 2014. Encapsulation and delivery of plasmid DNA by virus-like 

179: 140-146. doi: 10.1016/j.virusres.2013.10.021.

457

458

459

460

461

462

463

464

465

466

467

468

469

470

471

472

473

474

475

Johnson KN, Zeddam J-L, Ball LA. 2000. Characterization and construction of functional cDNA clones of Pariacoto virus, the first Alphanodavirus isolated outside Australasia. Journal of Virology 74: 5123-5132.

Kalia M, Jameel S. 2011. Virus entry paradigms. Amino Acids 41: 1147-1157. doi: 10.1007/s00726-009-0363-3.

Kalderon D, Richardson WD, Markham AF, Smith AA. 1984. Sequence requirements for nuclear location of simian virus 40 large-T antigen. Nature 311: 33-38. doi: $10.1038 / 311033 \mathrm{a} 0$.

Kim A, Shin TH, Shin SM, Pham CD, Choi DK, Kwon MH, Kim YS. 2012. Cellular internalization mechanism and intracellular trafficking of filamentous M13 phages displaying a cell-penetrating transbody and TAT peptide. PLoS One 7: e51813. doi: 10.1371/journal.pone.0051813.

Kosugi S, Hasebe M, Tomita M, Yanagawa H. 2009. Systematic identification of yeast cell cycle-dependent nucleocytoplasmic shuttling proteins by prediction of composite motifs. Proceedings of the National Academy of Sciences of the United States of America 106: 10171-10176. doi: 10.1073/pnas.0900604106.

Li H-C, Huang E-Y, Su P-Y, Wu S-Y, Yang C-C, Lin Y-S, Chang W-C, Shih C. 2010. Nuclear export and import of human hepatitis B virus capsid protein and particles. PLoS Pathogens 6: e1001162. doi: 10.1371/journal.ppat.1001162. 
476 Liu W, Hsu C, Hong Y, Wu S, Wang C, Wu Y, Chao C, Lin C. 2005. Early endocytosis

477

478

479

480

481

482

483

484

485

486

487

488

489

490

491

492

493

494

495

496

497 pathways in SSN-1 cells infected by dragon grouper nervous necrosis virus. Journal of General Virology 86: 2553-2561. doi: 10.1099/vir.0.81021-0.

Nair CM, Salin KR. 2012. Current status and prospects of farming the giant river prawn Macrobrachium rosenbergii (De Man) and the monsoon river prawn Macrobrachium malcolmsonii (H. M. Edwards) in India. Aquaculture Research 43: 999-1014. doi: 10.1111/j.1365-2109.2011.03074.x.

Naveenkumar S, Shekar M, Karunasagar I, Karunasagar I. 2013. Genetic analysis of RNA1 and RNA2 of Macrobrachium rosenbergii nodavirus (MrNV) isolated from India. Virus Research 173: 377-385. doi: 10.1016/j.virusres.2013.01.003.

Netsawang J, Noisakran S, Puttikhunt C, Kasinrerk W, Wongwiwat W, Malasit P, Yenchitsomanus P, Limjindaporn T. 2010. Nuclear localization of dengue virus capsid protein is required for DAXX interaction and apoptosis. Virus Research 147: 275-283. doi: 10.1016/j.virusres.2009.11.012.

Odegard AL, Kwan MH, Walukiewicz HE, Benerjee M, Shneemann A, Johnson JE. 2009. Low endocytic $\mathrm{pH}$ and capsid protein autocleavage are critical components of Flock House virus cell entry. Journal of Virology 83: 8628-8637. doi: 10.1128/JVI.00873-09.

Odegard A, Banerjee M, Johnson JE. 2010. Flock House virus : a model system for understanding non-enveloped virus entry and membrane penetration. Current Topics in Microbiology and Immunology 343: 1-22. doi: 10.1007/82_2010_35.

Ohtsuki T, Miki S, Kobayashi S, Haraguchi T, Nakata E, Hirakawa K, Sumita K, Watanabe K, Okazaki S. 2015. The molecular mechanism of photochemical internalization of cell 
498

499

500

501

502

503

504

505

506

507

508

509

510

511

512

513

514

515

516

517

518

519

520

penetrating peptide-cargo-photosensitizer conjugates. Scientific Reports 5: 18577. doi: 10.1038/srep18577.

Pillai D, Bonami JR. 2012. A review on the diseases of freshwater prawns with special focus on white tail disease of Macrobrachium rosenbergii. Aquaculture Research 43: 1029-1037. doi: 10.1111/j.1365-2109.2011.03061.x.

Qian D, Shi Z, Cao Z, Liu W, Li L, Xie Y, Cambournac I, Bonami J-R. 2003. Extra small viruslike particles (XSV) and nodavirus associated with whitish muscle disease in the giant freshwater prawn, Macrobrachium rosenbergii. Journal of Fish Diseases 26: 521-527.

Rodal SK, Skretting G, Garred O, Vilhardt F, van Deurs B, Sandvig K. 1999. Extraction of cholesterol with methyl-beta-cyclodextrin perturbs formation of clathrin-coated endocytic vesicles. Molecular Biology of the Cell 10: 961-974.

Tang KFJ, Pantoja CR, Redman RM, Lightner DV. 2007. Development of in situ hybridization and RT-PCR assay for the detection of a nodavirus $(P v \mathrm{NV})$ that causes muscle necrosis in Penaeus vannamei. Diseases of Aquatic Organisms 75: 183-190.

Yong CY, Yeap SK, Goh ZH, Ho KL, Omar AR, Tan WS. 2015a. Induction of humoral and cellmediated immune responses by hepatitis B virus epitope displayed on the virus-like particles of prawn nodavirus. Applied and Environmental Microbiology 81: 882-889. doi: 10.1128/AEM.03695-14.

Yong CY, Yeap SK, Ho KL, Omar AR, Tan WS. 2015b. Potential recombinant vaccine against influenza A virus based on M2e displayed on nodaviral capsid nanoparticles. International Journal of Nanomedicine 10: 2751-2763. doi: 10.2147/IJN.S77405. 
Figure Legends

525

526

Figure 1:

527 Triple fluorescence labelling and detection of MrNvc VLPs in Sf9 cells. (A) Sf9 cells in the 528 absence of $M r N v c$ VLPs, (B) Sf9 cells incubated with non-labelled $M r N v c$ VLPs and (C) Sf9 529 cells incubated with F-MrNvc VLPs. The cell nucleus and cytoplasm were labelled with 530 NucBlue Live Ready Probe Reagent (blue) and Cell Tracker Orange (red), respectively. PH 531 indicates images captured under white light. Merge images represent the superimposed green, 532 blue and red signals. (D) Small granular appearance in a Sf9 cell incubated with F-MrNvc VLPs 533 is indicated by the arrows. Bars, $10 \mu \mathrm{m}$.

534

535

Figure 2:

$536 \mathrm{MrNvc}$ distribution in Sf9 cytoplasmic and nuclear components. (A) Western blot analysis of the 537 cytoplasmic and nuclear components of Sf9 cells incubated with $M r \mathrm{Nvc}$ VLPs $(25 \mu \mathrm{g} / \mathrm{ml})$ at 538 different time $(0,4,8,12$ and 16 h). Both cytoplasmic and nuclear extracts were probed with 539 rabbit anti-MrNv serum [A(i)] and anti-His antibody [A(ii)]. (B-C) The orthogonal view from 540 the Z-stack images of the green fluorescence in the nucleus (B) and cytoplasm (C) of Sf9 cells

541 incubated with $M r N v c$ VLPs. Blue fluorescence indicates the cell nucleus. Interception of 542 yellow lines shows the location of the green fluorescent spots (F-MrNvc VLPs). Bars, $5 \mu \mathrm{m}$. 


\section{Figure 3:}

545 Effect of endosomal inhibitors on the entry of $M r N v c$ VLPs into Sf9 cells. Sf9 cells were pre-

546 incubated with different endosomal inhibitors: [A(iii)] cytochalasin $\mathrm{D}(2 \mu \mathrm{M})$, [A(iv)] $\mathrm{NH}_{4} \mathrm{Cl}$

$547(10 \mathrm{mM}),[\mathbf{A}(\mathbf{v})] \mathrm{CPZ}(50 \mu \mathrm{M}),[\mathbf{A}(\mathbf{v i})]$ methyl- $\beta$-cyclodextrin $(2 \mathrm{mM})$ and $[\mathbf{A}(\mathbf{v i i})]$ genistein

$548(100 \mu \mathrm{M}) . M r \mathrm{Nvc}$ VLPs labelled with NHS-fluorescein (F-MrNvc VLPs; $25 \mathrm{mg} / \mathrm{ml})$ were added

549 to each pre-treated sample and incubated for $16 \mathrm{~h}$ in the presence of endosomal inhibitors. Bars,

$55020 \mu \mathrm{m}$. [A(ii)] Sf9 cells added with F-MrNvc VLPs but without any inhibitor serve as positive

551 control, whereas [A(i)] Sf9 cells without any inhibitor nor F-MrNvc VLPs serve as negative

552 control. (B) MTT assay showing the viability of Sf9 cells in the presence of inhibitors.

553

554 Figure 4:

555 Trafficking mechanism of MrNvc VLPs into Sf9 cells. (A-E) Live cell imaging of the formation

556 of endosomes and endosomal escape of F-MrNvc VLPs. Sf9 cells were incubated with F-MrNvc

557 VLPs at $4^{\circ} \mathrm{C}$ for $1 \mathrm{~h}$ and shifted to $\mathrm{RT}$ for $30 \mathrm{~min}$ before they were viewed under a live cell

558 imaging system. Each image was captured in $30 \mathrm{~s}$ time lapse for $1 \mathrm{~h}$ (Video S1). White arrows

559 indicate endosome formation and red arrows show endosome formation to endosomal escape of

560 VLPs. The live cell imaging image shows (A) the attached F-MrNvc VLPs were gathered

561 around a hollow membrane pit, and (B) accumulated inside the pit. (C) Endosome enclosing the

562 VLPs was formed. (D) The size and shape of the endosome become disproportionate and (E) F-

$563 \mathrm{MrNvc}$ was released into the cytosol. These images were captured at the specified duration of 564 time lapse (Video S1). (F) A schematic diagram summarising the whole process. Bars, (A-E) 5 $565 \mu \mathrm{m}$. 


\section{Figure 5:}

568 Sub-cellular localization of the N-terminal deletion mutants of $M r \mathrm{Nvc}$ in Sf9 cells. (A) Four

569 mutants and the full length $M r \mathrm{Nvc}$ were used to infect Sf9 cells for $16 \mathrm{~h}$. (B) The cytoplasm and

570 nuclear components were extracted and analysed with Western blotting by using rabbit anti-

$571 M r N v$ serum to examine the localisation sites. Sf9 cells served as negative controls. (C) The N-

572 terminal mutants and the full length capsid proteins were labelled with NHS-fluorescein and

573 viewed under a fluorescence microscope. Blue colour indicates the cell nucleus. The merge

574 images are the superimposed images of blue and green signals. Bars, $20 \mu \mathrm{m}$. 


\section{Figure 1}

Triple fluorescence labeling and detection of MrNvc VLPs in Sf9 cells.

(A) Sf9 cells in the absence of MrNvc VLPs, (B) Sf9 cells incubated with non-labeled MrNvc VLPs and (C) Sf9 cells incubated with F-MrNvc VLPs. The cell nucleus and cytoplasm were labeled with NucBlue Live Ready Probe Reagent (blue) and Cell Tracker Orange (red), respectively. PH indicates images captured under white light. Merge images represent the superimposed green, blue and red signals. (D) Small granular appearance in a Sf9 cell incubated with F-MrNvc VLPs is indicated by the arrows. Bars, $10 \mu \mathrm{m}$. 


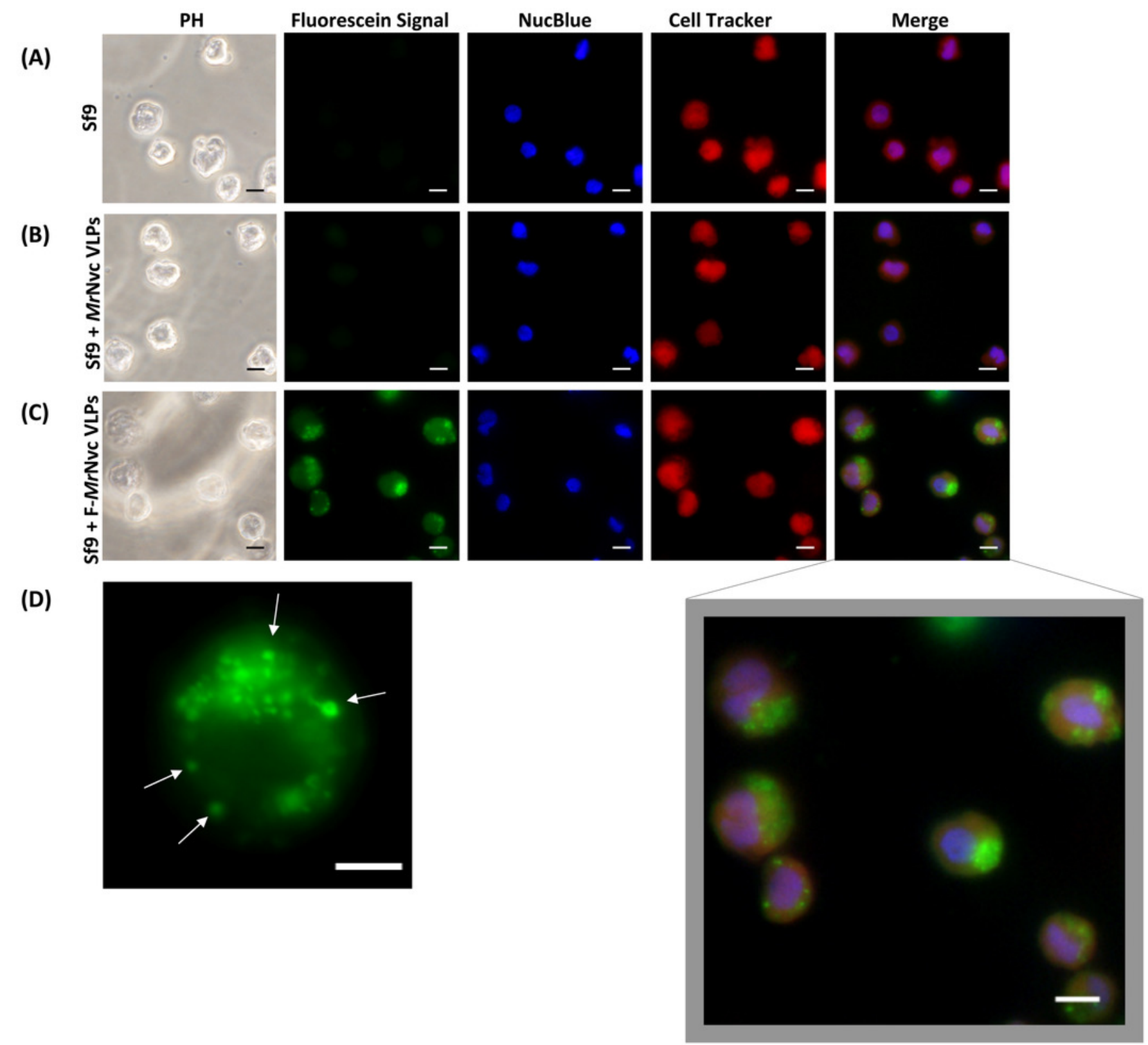




\section{Figure 2}

MrNvc distribution in Sf9 cytoplasmic and nuclear components.

(A) Western blot analysis of the cytoplasmic and nuclear components of Sf9 cells incubated with MrNvc VLPs $(25 \mu \mathrm{g} / \mathrm{ml})$ at different time $(0,4,8,12$ and $16 \mathrm{~h})$. Both cytoplasmic and nuclear extracts were probed with rabbit anti-MrNv serum [A(i)] and anti-His antibody [A(ii)]. (B-C) The orthogonal view from the Z-stack images of the green fluorescence in the nucleus (B) and cytoplasm (C) of Sf9 cells incubated with MrNvc VLPs. Blue fluorescence indicates the cell nucleus. Yellow lines interception shows the location of the green fluorescent spots (F-MrNvc VLPs). Bars, $5 \mu \mathrm{m}$. 
(A)






\section{Figure 3}

Effect of endosomal inhibitors on the entry of MrNvc VLPs into Sf9 cells.

Sf9 cells were pre-incubated with different endosomal inhibitors: [A(iii)] cytochalasin D (2 $\mu \mathrm{M})$, [A(iv)] $\mathrm{NH}_{4} \mathrm{Cl}(10 \mathrm{mM}),[\mathbf{A}(\mathbf{v})] \mathrm{CPZ}(50 \mu \mathrm{M})$, [A(vi)] methyl- $\beta$-cyclodextrin $(2 \mathrm{mM})$ and [A(vii)] genistein (100 $\mu$ M). MrNvc VLPs labelled with NHS-fluorescein (F-MrNvc VLPs; 25 $\mathrm{mg} / \mathrm{ml}$ ) were added to each pre-treated sample and incubated for $16 \mathrm{~h}$ in the presence of endosomal inhibitors. Bars, $20 \mu \mathrm{m}$. [A(ii)] Sf9 cells added with F-MrNvc VLPs but without any inhibitor serve as positive control, whereas [A(i)] Sf9 cells without any inhibitor nor F-MrNvc VLPs serve as negative control. (B) MTT assay showing the viability of Sf9 cells in the presence of inhibitors.

(A)

(i) Sf9 (negative control)

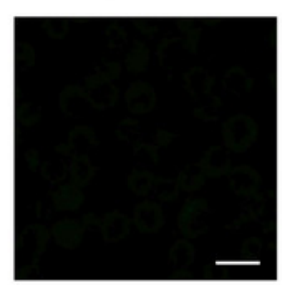

(iv) $\mathrm{Sf9}+10 \mathrm{mM} \mathrm{NH}_{4} \mathrm{Cl}$
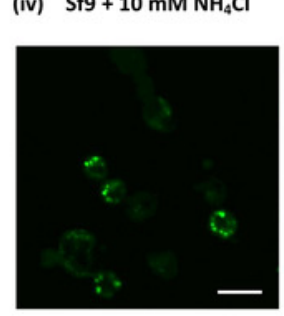

(ii) Sf9 (positive control)



(v) $\quad$ Sf9 $+50 \mu \mathrm{M} \mathrm{CPZ}$

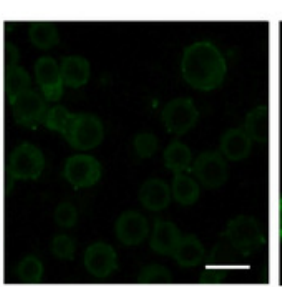

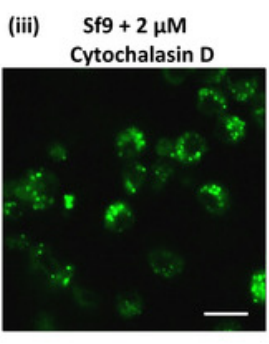

(vi) Sf9 + 2 mM Methyl- $\beta \quad$ (vii) Sf9 + $100 \mu \mathrm{M}$ Genistein -cyclodextrin

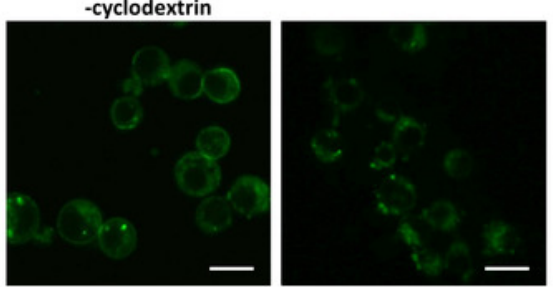

(B)

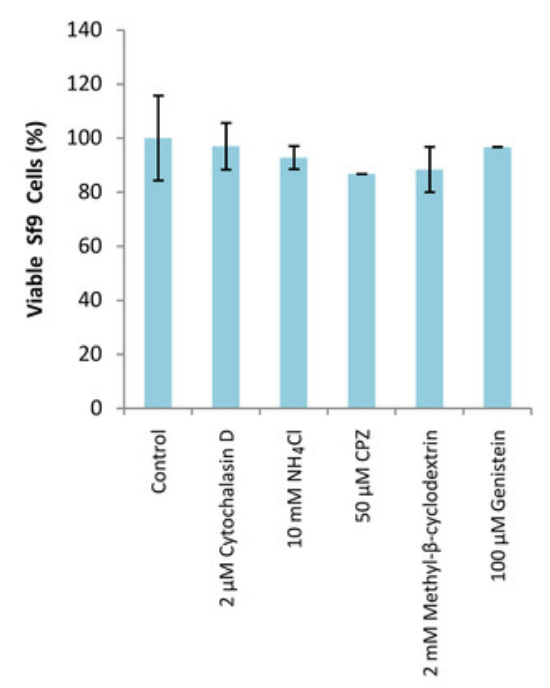




\section{Figure 4}

Trafficking mechanism of MrNvc VLPs into Sf9 cells.

(A-E) Live cell imaging of the formation of endosomes and endosomal escape of F-MrNvc VLPs. Sf9 cells were incubated with F-MrNvc VLPs at $4^{\circ} \mathrm{C}$ for $1 \mathrm{~h}$ and shifted to RT for $30 \mathrm{~min}$ before they were viewed under a live cell imaging system. Each image was captured in $30 \mathrm{~s}$ time lapse for $1 \mathrm{~h}$ (Video S1). White arrows indicate endosome formation and red arrows show endosome formation to endosomal escape of VLPs. The live cell imaging image shows (A) the attached F-MrNvc VLPs were gathered around a hollow membrane pit, and (B) accumulated inside the pit. (C) Endosome enclosing the VLPs was formed. (D) The size and shape of the endosome become disproportionate and (E) F-MrNvc was released into the cytosol. These images were captured at the specified duration of time lapse (Video S1). (F) A schematic diagram summarising the whole process. Bars, (A-E) $5 \mu \mathrm{m}$. 




00:00:02:30

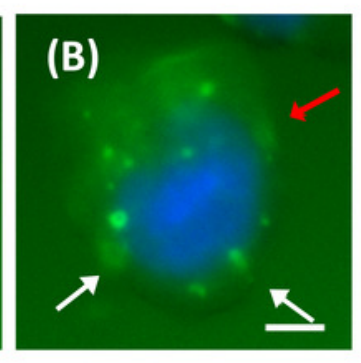

00:00:04:00

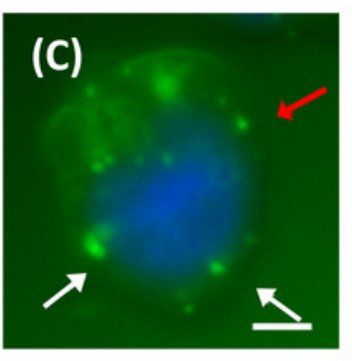

00:00:09:00

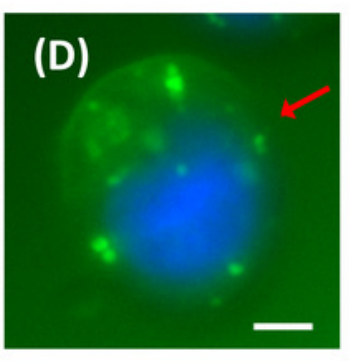

00:00:19:00

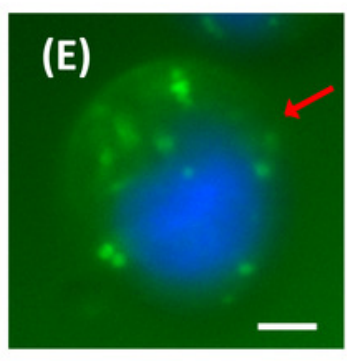

00:00:24:30

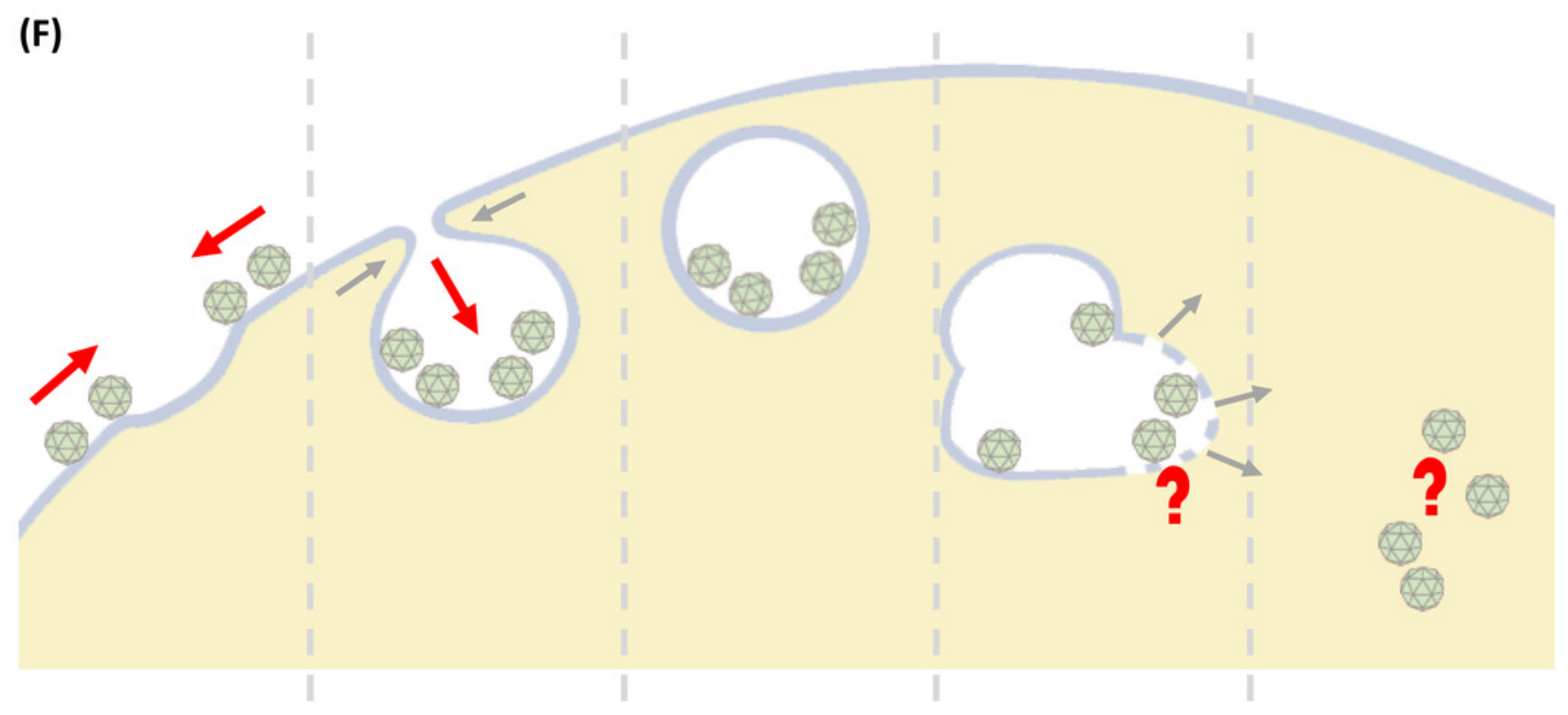




\section{Figure 5}

Sub-cellular localization of the N-terminal deletion mutants of MrNvc in Sf9 cells.

(A) Four mutants and the full length MrNvc were used to infect Sf9 cells for $16 \mathrm{~h}$. (B) The cytoplasm and nuclear components were extracted and analyzed with Western blotting by using rabbit anti-MrNv serum to examine the localization sites. Sf9 cells served as negative controls. (C) The N-terminal mutants and the full length capsid proteins were labeled with NHS-fluorescein and viewed under a fluorescence microscope. Blue color indicates the cell nucleus. The merge images are the superimposed images of blue and green signals. Bars, 20 $\mu \mathrm{m}$.

(A)
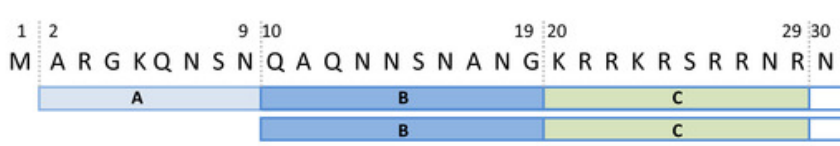

\section{C}

MrNvc
$9 \Delta \mathrm{MrNvc}$

$19 \Delta M r N v c$

$29 \Delta$ MrNvc

20-29 $\triangle M r N v c$

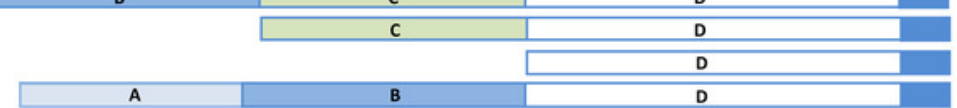

(B)

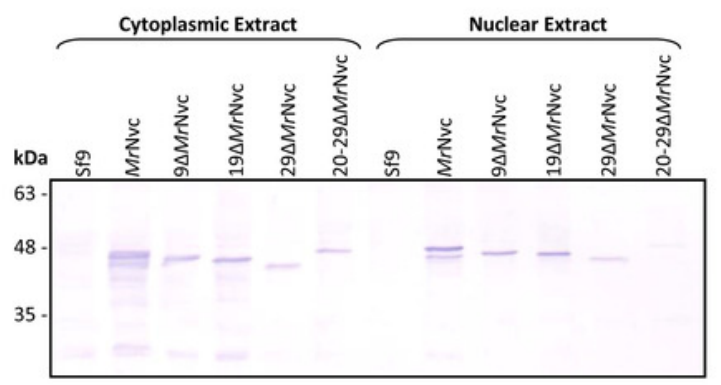

(C)
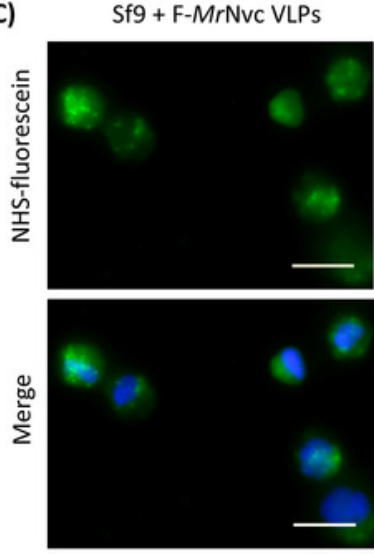

Sf9 + F-9 $\Delta$ MrNvc VLPs
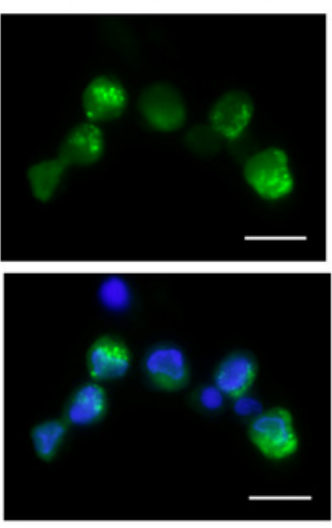

Sf9 + F-19 MMrNvc VLPS
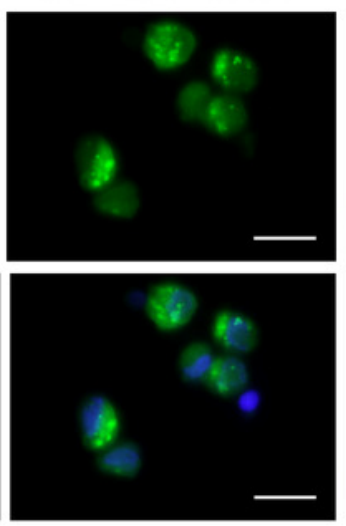

Sf9 + F-29 $\Delta$ MrNvc VLPs
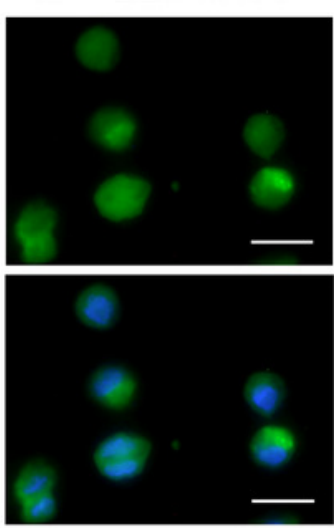

Sf9 + F-(20-29) $\Delta M r N v c$ VLPS
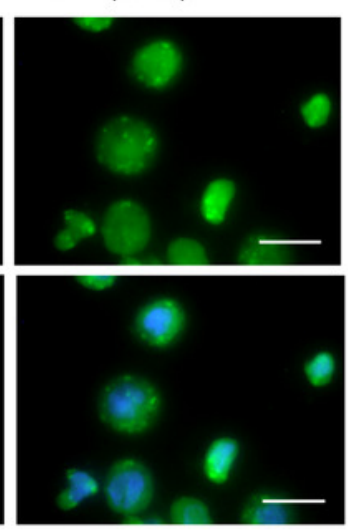